\title{
Własności i struktura złączy spawanych hybrydowo HLAW (wiązka laserowa - FCAW) stali obrabianej termomechanicznie S700MC
}

\author{
The properties and structure \\ of the hybrid welded joints HLAW (laser beam - FCAW) \\ thermomechanically treated steel S700MC
}

\section{Streszczenie}

W artykule przedstawiono strukturę i własności złączy spawanych hybrydowo HLAW (wiązka laserowa - FCAW) stali obrabianej termomechanicznie o wysokiej granicy plastyczności S700MC o grubości $10 \mathrm{~mm}$, przy użyciu materiału dodatkowego w postaci drutu proszkowego Stein-Megafil 742 B o średnicy $1,2 \mathrm{~mm}$. Przeprowadzone badania nieniszczące pozwoliły sklasyfikować złącza w poziomie jakości B zgodnie z ISO 12932. Przeprowadzone badania niszczące wykazały, że złącze charakteryzuje się wytrzymałością na rozciąganie zbliżoną do wytrzymałości materiału rodzimego. Proces spawania hybrydowego (wiązka laserowa - FCAW) stali S700MC pozwala na zapewnienie wysokich własności plastycznych złączy spawanych. W każdym obszarze złącza spawanego wartości udarności spełniają kryteria minimalnej dopuszczalnej wartości udarności. Przeprowadzone badania wykazały, że istnieje możliwość wykonania złączy spawanych, spełniających wymagania ISO 15614-14.

Słowa kluczowe: stal S700MC, spawanie hybrydowe, HLAW

\section{Abstract}

This paper presents the structure and properties of welded joints hybrid HLAW (laser beam - FCAW) thermomechanically treated steel with a high yield S700MC a thickness of $10 \mathrm{~mm}$, using additional material in the form of a wire powder Stein-Megafil 742 B having a diameter of $1.2 \mathrm{~mm}$. The study made it possible to classify non-destructive welded joints on the quality level $B$ in accordance with ISO 12932. Destructive testing showed that the welded joints have a tensile strength similar to the strength of the base material. Hybrid welding process (laser beam - FCAW) S700MC steel ensures the high plastic properties of welded joints. In every area of the weld joint toughness values meet the criteria for the minimum limit impact. The study showed that there is a possibility to make welded joints that meet the requirements of ISO 15614-14.

Keywords: S700MC steel, hybrid welding, HLAW

\section{Wstęp}

Obecnym trendem panującym na całym świecie jest ciągły rozwój polegający na wprowadzaniu nowych rozwiązań technologicznych lub ulepszaniu już istniejących, które dotyczą różnych dziedzin życia. Nie inaczej jest w przemyśle ciężkim, który od zawsze dąży do zwiększenia wydajności produkcji przy zmniejszeniu kosztów wytwarzania produktów. Dlatego coraz częściej podczas łączenia metali i ich stopów zastosowanie znajdują wysokowydajne procesy spawania, dzięki którym możliwe jest uzyskanie wysokiej jakości połączeń spawanych przy zapewnieniu wysokiej efektywności procesu łączenia oraz obniżeniu nakładów pracy. Ten kierunek rozwoju doprowadził do udoskonalania istniejących już metod spawania, czego rezultatem było opracowanie, pod koniec XX wieku, technologii spawania hybrydowego. Jednak dopiero w ostatnich latach proces ten zaczyna cieszyć się coraz większą popularnością i z powodzeniem znajduje zastosowanie miedzy innymi w przemyśle stoczniowym czy motoryzacyjnym, gdzie stopniowo zastępuje proces spawania laserowego. Spawanie hybrydowe jest połączeniem dwóch różnych spawalniczych źródeł ciepła: łuku elektrycznego oraz promienia laserowego. Jako źródła laserowe w metodzie HLAW można stosować dowolne lasery przemysłowe, jednakże znaczący rozwój w ostatnich latach laserów na ciekle stałym (lasery dyskowe i lasery włóknowe) spowodował, że obecnie są one najczęściej dobieranymi źródłami promieniowania laserowego do metody hybrydowej. Jako metodę łukową spawania w procesie spawania hybrydowego HLAW najczęściej stosuje się metody łukowe, w których elektrodę stanowi materiał dodatkowy podawany do obszaru spawania w sposób ciągły

Dr hab. inż. Jacek Górka - Politechnika Śląska w Gliwicach, dr inż. Sebastian Stano - Instytut Spawalnictwa w Gliwicach Autor korespondencyjny/Corresponding author.jacek.gorka@polsı.pl 
(MIG, MAG). Zastosowanie kombinacji tych metod spawania pozwoliło na wykorzystanie ich zalet w jednym procesie spawania. W efekcie uzyskano wysoką koncentrację ciepła w miejscu łączonych elementów, co pozwoliło na wykonywanie spoin o niewielkiej szerokości oraz bardzo dużej głębokości wtopienia. Materiał dodatkowy umożliwia regulację składu chemicznego spoiny poprzez wprowadzenie odpowiednich składników stopowych do jeziorka spawalniczego oraz prawidłowy przebieg procesu spawania w przypadku zestawienia blach ze szczeliną (w przypadku spawania laserowego elementy do spawania powinny być zestawione bez szczeliny). Obserwowany jest efekt synergicznego oddziaływania dwóch źródeł ciepła, procesy wzajemnie się stabilizują, umożliwiając często uzyskanie większych prędkości spawania niż dla klasycznego procesu spawania laserowego. Uzyskuje się znaczne zwiększenie wydajności procesu spawania, nie tylko poprzez zwiększenie prędkości spawania, ale także poprzez brak lub znaczne ograniczenie ukosowania krawędzi łączonych blach i zmniejszenie odkształceń w spawanych elementach (skrócenie czasu na prostowanie konstrukcji). Proces spawania hybrydowego może być szczególnie przydatny w wielkogabarytowej produkcji przemysłowej ze względu na większą tolerancję $\mathrm{w}$ przygotowaniu elementów do spawania, możliwość łączenia blach w jednym przejściu oraz niższą dokładność w pozycjonowaniu względem siebie łączonych blach [1 $\div 8]$.

Równolegle do rozwoju nowoczesnych metod spawania postępuje rozwój w dziedzinie nowych materiałów konstrukcyjnych, którymi są między innymi stale o wysokich własnościach wytrzymałościowych przeznaczone na konstrukcje spawane. Aby obniżyć koszty produkcji tego rodzaju stali oraz zachować ich wysokie własności wytrzymałościowe, nie pogarszając znacząco spawalności tych materiałów, zaczęto wytwarzać stale konstrukcyjne z mikrododatkami oraz stosować procesy dodatkowo zwiększające wytrzymałość. Przykładem tego typu materiałów są stale walcowane termomechanicznie. Do produkcji takich stali stosuje się mniejszą ilość dodatków stopowych. Proces wytwarzania obejmuje mniej operacji i zabiegów technologicznych, co znacząco obniża całkowity koszt produkcji takiej stali. Dlatego obecnie na rynku istnieje bardzo duża liczba gatunków stali konstrukcyjnych z mikrododatkami o granicy

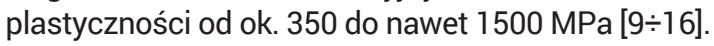

\section{Badania własne}

Celem badań było określenie własności złączy doczołowych blach o grubości $10 \mathrm{~mm}$ ze stali S700MC spawanych hybrydowo (wiązka laserowa - FCAW) na podkładce miedzianej, przy użyciu materiału dodatkowego w postaci drutu proszkowego Stein-Megafil 742 B o średnicy 1,2 mm. Skład chemiczny i własności stali przedstawia tablica I.

Tablica I. Skład chemiczny wg PN EN 10149-2 i własności mechaniczne stali walcowanej termomechanicznie do kształtowania na zimno S700MC

Table I. The chemical composition according to the regulation PN EN 10149-2 and mechanical properties of the S700 MC steel subjected to thermomechanical treatment used for cold moulding

\begin{tabular}{|c|c|c|c|c|c|c|c|c|c|c|c|}
\hline \multicolumn{12}{|c|}{ Stężenie pierwiastków, \% } \\
\hline $\begin{array}{c}\mathrm{C} \\
\max .\end{array}$ & $\begin{array}{c}\mathrm{Si} \\
\max \end{array}$ & $\begin{array}{l}\text { Mn } \\
\max .\end{array}$ & $\begin{array}{l}P \\
\max \end{array}$ & $\begin{array}{c}S \\
\max \end{array}$ & $\begin{array}{l}\mathrm{Al}_{\text {catk. }} \\
\text { min. }\end{array}$ & $\begin{array}{c}\mathrm{Nb} \\
\mathrm{max}^{*} \text {. }\end{array}$ & $\begin{array}{c}\mathrm{V} \\
\max .\end{array}$ & $\begin{array}{c}\mathrm{Ti} \\
\max .\end{array}$ & $\begin{array}{c}B \\
\max .\end{array}$ & $\begin{array}{l}\text { Mo } \\
\max .\end{array}$ & $\begin{array}{l}\mathrm{Ce}^{\star *} \\
\max .\end{array}$ \\
\hline 0,12 & 0,60 & 2,10 & 0,008 & 0,015 & 0,015 & 0,09 & 0,20 & 0,22 & 0,005 & 0,50 & 0,61 \\
\hline \multicolumn{12}{|c|}{ Własności mechaniczne } \\
\hline \multicolumn{3}{|c|}{$\begin{array}{l}\text { Wytrzymałość na } \\
\text { rozciąganie Rm, Mpa }\end{array}$} & \multicolumn{3}{|c|}{ Granica plastyczności Re, MPa } & \multicolumn{3}{|c|}{ Wydłużenie $A_{5}, \%$} & \multicolumn{3}{|c|}{$\begin{array}{c}\text { Udarność, } \mathrm{J} / \mathrm{cm}^{2} \\
\left(-20^{\circ} \mathrm{C}\right)\end{array}$} \\
\hline \multicolumn{3}{|c|}{822} & \multicolumn{3}{|c|}{768} & \multicolumn{3}{|c|}{19} & \multicolumn{3}{|c|}{135} \\
\hline
\end{tabular}

\section{Proces spawania}

Złącza spawane zostały wykonane na stanowisku zrobotyzowanym (rys. 1) w Instytucie Spawalnictwa w Gliwicach. Do badań wykorzystano cele roboczą TruLaser Robot 5120 wyposażoną w laser dyskowy TruDisk 12002 firmy TRUMPF o mocy 12000 W oraz synergiczne źródło prądu EWM Phoenix 452 RC PULS. Głowica do spawania hybrydowego (wiązka lasera - FCAW) zamocowana została na kiści robota. Ogniskowa soczewki kolimatora była równa $\mathrm{f}_{\mathrm{c}}=200 \mathrm{~mm}$, ogniskowa soczewki skupiającej $\mathrm{f}_{\mathrm{o}}=400 \mathrm{~mm}$, natomiast średnica ogniska wynosiła $D_{\text {og }}=0,8 \mathrm{~mm}$ (rys. 2). Średnica światłowodu doprowaDługość wolnego wylotu elektrody wynosiła l= $18 \mathrm{~mm}$. Jako gazu osłonowego użyto mieszankę M21 (18\% $\left.\mathrm{CO}_{2}+82 \% \mathrm{Ar}\right)$, natężenie przepływu ustalono na poziomie $18 \mathrm{l} / \mathrm{min}$. Materiał dodatkowy do spawania stanowił drut proszkowy Stein-Megafil 742 B o średnicy 1,2 mm. Elektroda została pochylona do powierzchni spawanej pod kątem $a=65^{\circ}$, natomiast odległość między jej końcem a wiązką laserową równa była $a=2 \mathrm{~mm}$ (rys. 2). Parametry wykonania złącza dobrane na podstawie badań wstępnych przedstawia tablica II.

Tablica II. Parametry spawania hybrydowego (wiązka laserowa - FCAW) stali S700MC o grubości $10 \mathrm{~mm}$

Table II. Hybrid welding parameters (laser beam - FCAW) S700MC steel with a thickness of $10 \mathrm{~mm}$

\begin{tabular}{|c|c|c|c|c|c|}
\hline \multicolumn{2}{|c|}{$\begin{array}{c}\text { Przygotowanie blach } \\
\text { do spawania }\end{array}$} & \multicolumn{3}{|c|}{$\begin{array}{c}\text { Kolejność układania } \\
\text { ściegów }\end{array}$} \\
\hline $\begin{array}{c}\text { Moc } \\
\text { wiązki } \\
\text { laserowej, } \\
\text { W }\end{array}$ & $\begin{array}{c}\text { Prędkość } \\
\text { spawania, } \\
\text { m/min }\end{array}$ & $\begin{array}{c}\text { Prędkość } \\
\text { podawania } \\
\text { drutu, } \\
\text { m/min }\end{array}$ & $\begin{array}{c}\text { Natężenie } \\
\text { prądu } \\
\text { spawania, } \\
\text { A }\end{array}$ & $\begin{array}{c}\text { Napiecie } \\
\text { tuku, } \\
\mathrm{V}\end{array}$ & $\begin{array}{c}\text { Szerokość } \\
\text { szczeliny, } \\
\text { mm }\end{array}$ \\
\hline 6000 & 1 & 11 & 275 & 30 & 0,8 \\
\hline
\end{tabular}

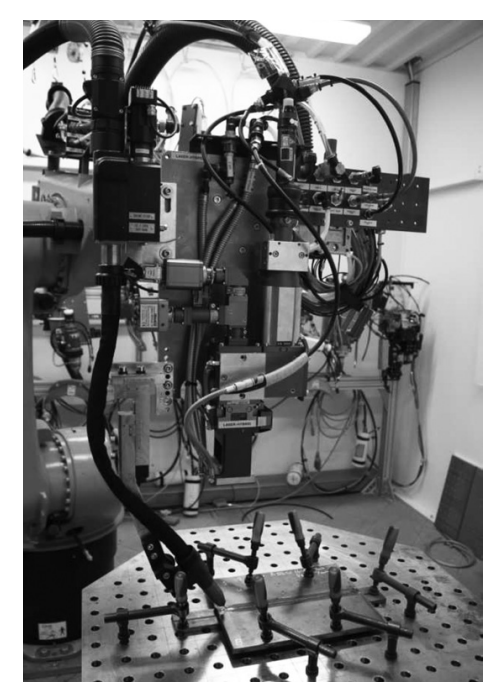

Rys. 1. Stanowisko do spawania hybrydowego (wiązka lasera - FCAW)

Fig. 1. Robotized hybrid weIding (laser beam - FCAW) dzającego energię z lasera do robota była równa $D_{s ́ w}=0,4 \mathrm{~mm}$. 

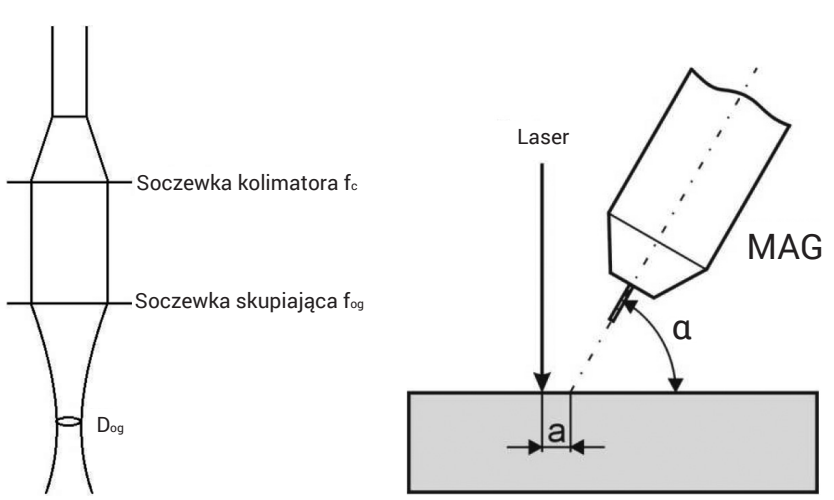

Rys. 2. Schemat układu optycznego lasera oraz wzajemne położenie wiązki laserowej i łuku elektrycznego w technologii hybrydowej Fig. 2. Schematic of the laser optical system and the mutual alignment of the laser beam and the electric arc hybrid technology

\section{Badania złączy spawanych}

Uzyskane złącze próbne poddano badaniom nieniszczącym:

- badaniom wizualnym na podstawie wymagań PN-EN ISO 17637:2011;

- badaniom magnetyczno-proszkowym ma podstawie wytycznych norm PN-EN ISO 3059:2005, PN-EN ISO 9934-2:2003, PN-EN ISO 9934-3:2003. Jako podkład kontrastowy biały zastosowano środek MR 72, natomiast do przeprowadzenia badań użyto proszku magnetycznego MR 76S, badania prowadzono z użyciem elektromagnesu jarzmowego;

- badaniom radiograficznym na podstawie PN-EN 1435 lampą rentgenowską CERAM typ 235 wiązką promieni $X$ o średnicy $\mathrm{d}=2 \mathrm{~mm}$ przy napięciu $\mathrm{U}=180 \mathrm{kV}$, natężeniu $\mathrm{I}=3 \mathrm{~mA}$, stosując okładki wzmacniające OW -0,15 mm. Wyniki badań rejestrowano na kliszy fotograficznej AGFA typ $\mathrm{C5}$, stosując czas naświetlania $\mathrm{t}=2,3 \mathrm{~min}$ i ogniskową f $=700 \mathrm{~mm}$. Do oceny jakości obrazu użyto wskaźnika pręcikowego 13FEEN.

Po przeprowadzeniu badań nieniszczących złącze spawane poddano badaniom niszczącym w takim zakresie jak:

- badania wytrzymałości na rozciąganie zgodnie z PN-EN ISO 6892-1:2010 na maszynie wytrzymałościowej typ ZWICK/ROELL Z 330RED na próbkach pobranych zgodnie z PN-EN ISO 4136:2011;

- próba zginania poprzecznego złącza doczołowego z rozciąganiem od strony lica spoiny (FBB) oraz zginania złącza doczołowego z rozciąganiem od strony grani spoiny (RBB) na podstawie PN-EN ISO 5173:2010. Próby zginania przeprowadzono za pomocą maszyny ZWICK/ROELL Z 330RED z dodatkowym modułem dla prób zginania z zastosowaniem trzpienia zginającego o średnicy 30 $\mathrm{mm}$. Odległość między rolkami ustalono na $60 \mathrm{~mm}$. W celu określenia położenia osi spoiny czoła próbek trawiono odczynnikiem Adlera;

- badania udarności zgodnie z PN-EN ISO 148-1:2010, na próbkach $\mathrm{z}$ karbem typu $\mathrm{V}$, na młocie udarowym ZWICK/ROELL RKP $450 \mathrm{w}$ temperaturze $-30{ }^{\circ} \mathrm{C}$. Z uwagi na grubość spawanych blach $(10 \mathrm{~mm})$ i konieczność wykonania niezbędnych zabiegów obróbki mechanicznej w celu przygotowania próbek wykonano próbki o pomniejszonym przekroju o grubości 7,5 mm, trawione w nitalu;

- badania metalograficzne makroskopowe na mikroskopie świetInym stereoskopowym Olympus SZX9; próbki do badań trawiono odczynnikiem Adlera;

- badania metalograficzne mikroskopowe na mikroskopie świetlnym NIKON ECLIPSE MA100; próbki do badań trawiono w nitalu;

- pomiar twardości za pomocą urządzenia Vickers 401MVD firmy Wilson Wolpert, przy obciążeniu $1 \mathrm{~kg}$, według schematu przedstawionego na rysunku 3.

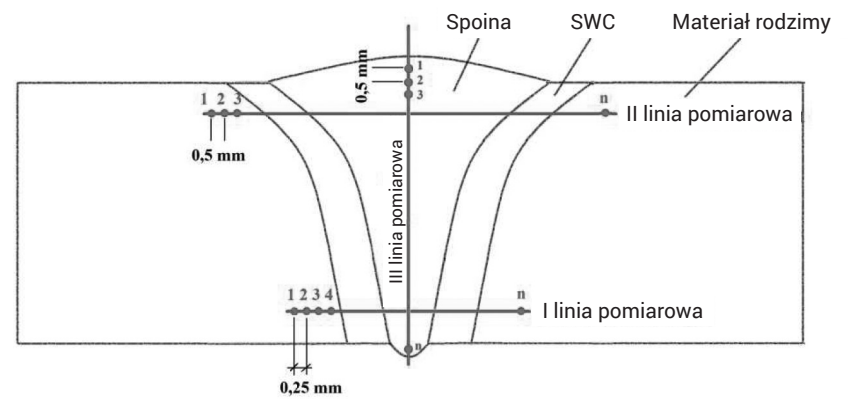

Rys. 3. Schemat linii pomiarowych badań twardości złączy spawanych Fig. 3. Schematic of measuring lines hardness testing of welded joints

\section{Analiza wyników badań}

Przeprowadzone badania wizualne oraz badania magnetyczno-proszkowe wykonanego złącza spawanego nie wykazały wychodzących na powierzchnię wad spawalniczych typu: pęknięcia, porowatość, przyklejenia, braki przetopu. Badania radiograficzne również nie wykazały wewnętrznych wad spawalniczych. Złącze spawane spełniało wymagania poziomu jakości B zgodnie z normą ISO 12932. Również badania makroskopowe nie wykazały niezgodności spawalniczych w obszarze spoiny i SWC (rys. 4).

Badania mikroskopowe w obszarze spoiny ujawniły strukturę bainityczno-ferrytyczną. Obszar strefy wpływu ciepła (SWC) charakteryzuje się zmiennością wielkości ziarna, co spowodowane jest stosunkowo dużą ilością ciepła dostarczoną podczas procesu spawania (rys. 5). Badania mikroskopowe wykazały również obecność wydzieleń azotkowych w obszarze SWC oraz w materiale rodzimym (rys. 6).

Analiza wyników badań niszczących doczołowego złącza spawanego hybrydowo (wiązka laserowa - FCAW) wykazała, że uzyskane złącze próbne spełnia wymagania ISO 15614-14 (tabl. III). W wyniku procesu spawania hybrydowego (wiązka lasera - FCAW) następuje nieznaczne obniżenie wytrzymałości na rozciąganie do poziomu ok. $795 \mathrm{MPa}$, w stosunku do wytrzymałości materiału rodzimego (820 MPa). Zerwanie następuje w obszarze SWC, gdzie pojawia się niewielki rozrost ziarna. To obniżenie wytrzymałości na rozciąganie jest związane z utratą własności, które stal S700MC nabyła w wyniku walcowania termomechanicznego. Próba zginania pozwoliła na osiągnięcia kąta gięcia na poziomie $180^{\circ}$, zarówno podczas rozciągania od strony lica jak i grani spoiny, co świadczy o wysokich własnościach plastycznych uzyskanego połączenia. Przeprowadzona próba udarności w temperaturze $-30{ }^{\circ} \mathrm{C}$, wykazała zadowalające wartości udarności, zarówno w obszarze spoiny, linii wtopienia i SWC. W obszarze spoiny udarność osiągnęła wartość $45 \mathrm{~J} / \mathrm{cm}^{2}$, w obszarze linii wtopienia nastąpił spadek udarności do poziomu $37 \mathrm{~J} / \mathrm{cm}^{2}$, natomiast w obszarze SWC nastąpił wyrost udarności do poziomu $50 \mathrm{~J} / \mathrm{cm}^{2}$, zbliżonej do udarności materiału rodzimego.

Przeprowadzone pomiary twardości $\mathrm{HV}_{1}$, wykazały że w obszarze linii wtopienia dochodzi do obniżenia twardości w stosunku do materiału rodzimego, twardość w tym obszarze osiąga wartość $250 \mathrm{HV}_{1}$, przy twardości materiału rodzimego na poziomie $280 \mathrm{HV}_{1}$. Również w obszarze SWC następuje spadek twardości w stosunku do materiału rodzimego. Wartość twardości w górnej części spoiny jest zbliżona do twardości materiału rodzimego (280 $\left.\mathrm{HV}_{1}\right)$ i jest wyższa od wartości zmierzonej w dolnej części spoiny o ok. $8 \%$. Spowodowane jest to faktem, iż w górnej części występuje więcej dodatków stopowych zwiększających hartowność (nikiel, chrom), które są dostarczone wraz z materiałem dodatkowym (rys. 7, 8). Zmiany rozkładu twardości w spoinie potwierdziły pomiary twardości wzdłuż osi spoiny (rys. 9). 
Tablica III. Własności wytrzymałościowe i plastyczne złącza spawanego hybrydowo (wiązka laserowa - FCAW) stali S700MC

Table III. Mechanical and plastic properties of welded joint hybrid (laser beam - FCAW) steel S700MC

\begin{tabular}{|c|c|c|c|c|c|c|}
\hline \multicolumn{2}{|c|}{ Rozciąganie* $^{\star}$} & \multicolumn{2}{|c|}{ Zginanie*, kąt gięcia, $^{\circ}$} & \multicolumn{3}{|c|}{$\begin{array}{c}\text { Udarność } \mathrm{KCV}^{\star *}, \mathrm{~J} / \mathrm{cm}^{2} \\
\text { (temperatura badania - 30 }\end{array}{ }^{\circ} \mathrm{C}$ ) } \\
\hline $\begin{array}{c}\mathrm{R}_{\mathrm{m}}, \\
\text { MPa }\end{array}$ & $\begin{array}{c}\text { Miejsce } \\
\text { zerwania }\end{array}$ & Lico & Grań & Spoina & LW & SWC \\
\hline 795 & SWC & 180 & 180 & 45 & 37 & 50 \\
\hline
\end{tabular}

* - wynik średni z dwóch pomiarów,

** - wynik średni z trzech pomiarów
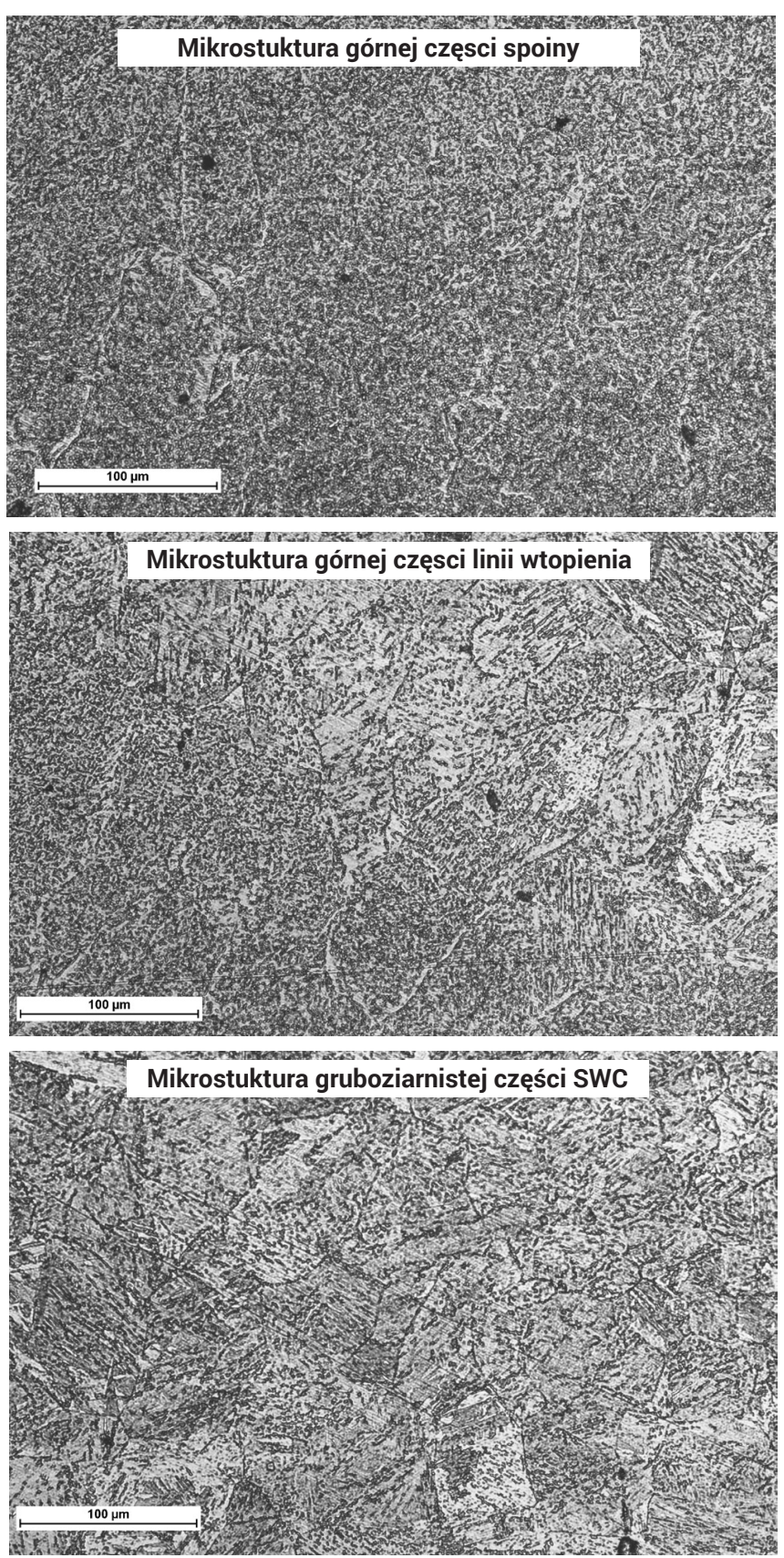

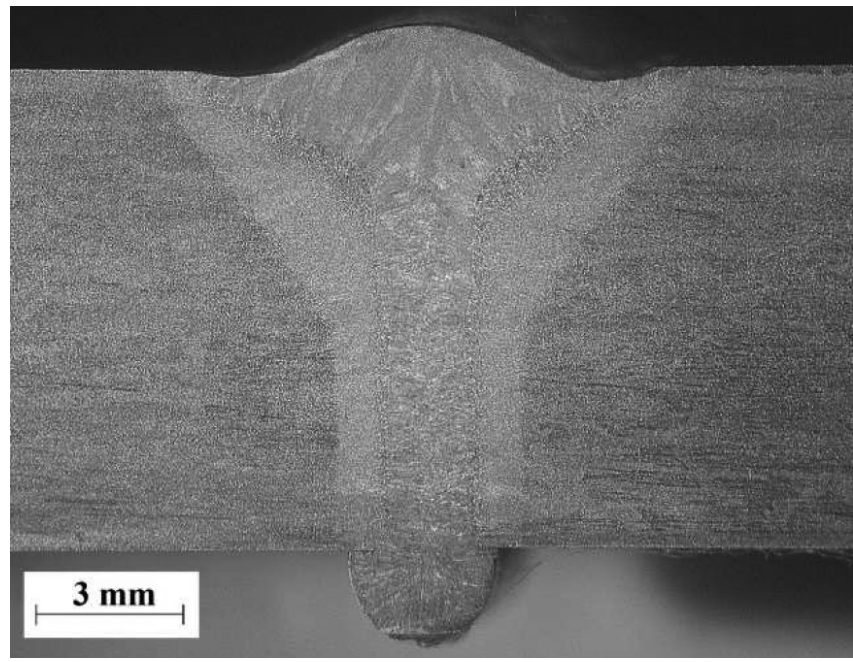

Rys. 4. Makrostruktura złącza spawanego hybrydowo (wiązką laserowa - FCAW) stali S700MC

Fig. 4. Macrostructure hybrid welded joint (laser beam - FCAW) steel S700MC
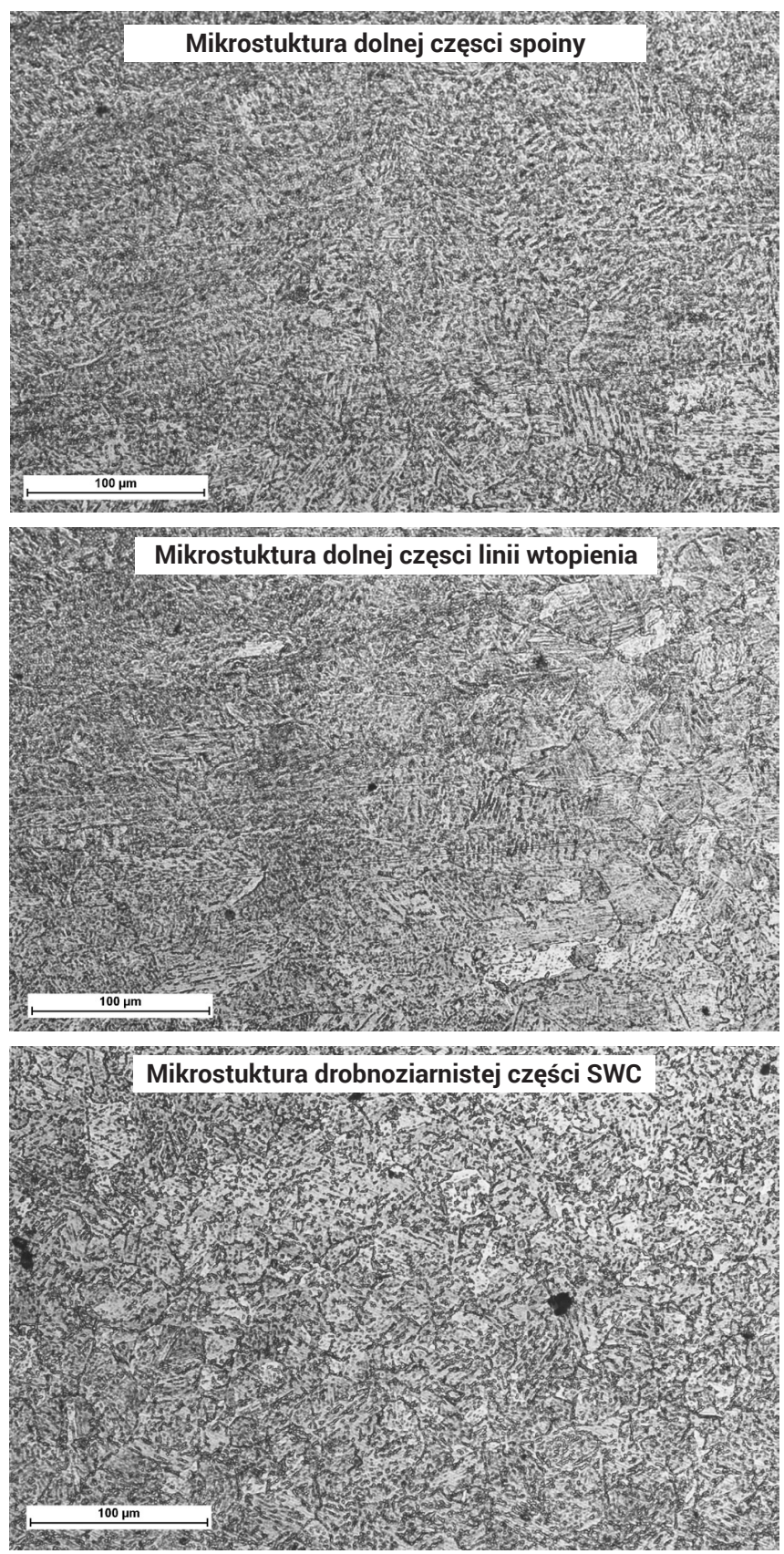

Rys. 5. Mikrostruktura złącza spawanego hybrydowo (laser - FCAW) stali S700MC

Fig. 5. Microstructure hybrid welded joint (laser beam - FCAW) steel S700MC 

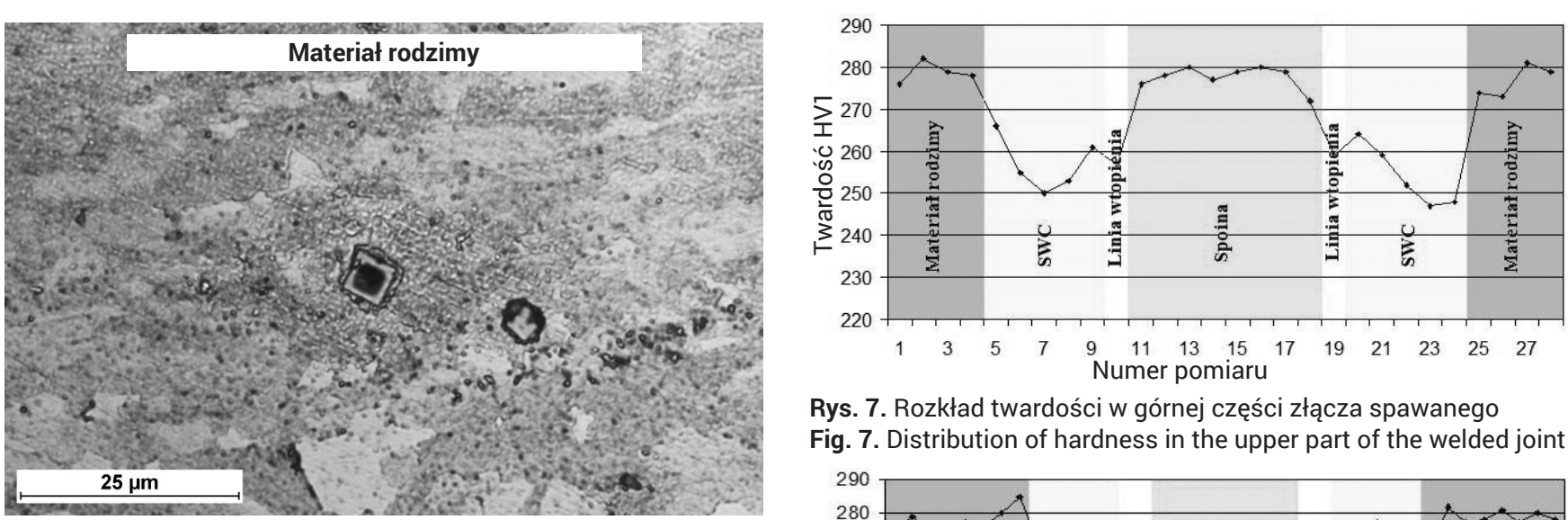

Rys. 7. Rozkład twardości w górnej części złącza spawanego

Fig. 7. Distribution of hardness in the upper part of the welded joint

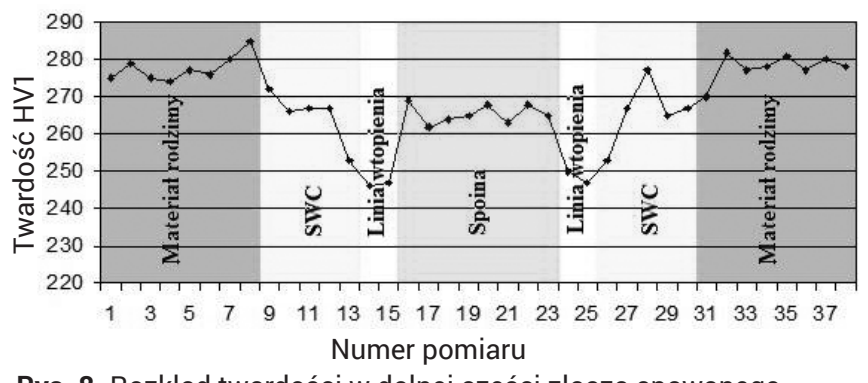

Rys. 8. Rozkład twardości w dolnej części złącza spawanego

Fig. 8. Distribution of hardness in the lower part of the welded joint

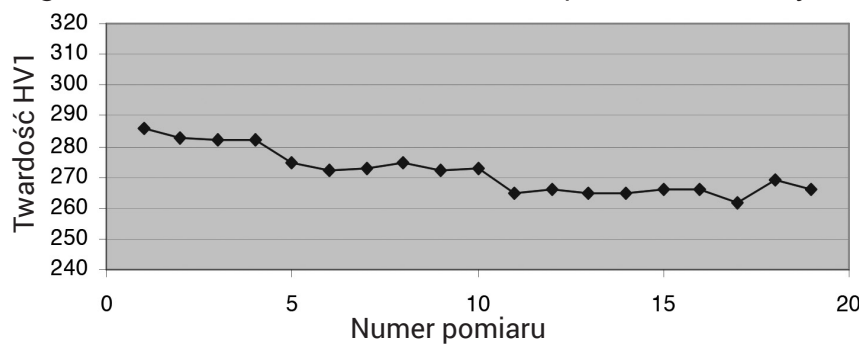

Rys. 9. Rozkład twardości w osi spoiny

Fig. 9. Distribution of hardness in the weld axis

\section{Podsumowanie}

Przeprowadzone badania procesu spawania hybrydowego (wiązka laserowa - FCAW) stali S700MC o grubości 10 mm, przy użyciu materiału dodatkowego w postaci drutu proszkowego Stein-Megafil 742B, wykazały, że istnieje możliwość wykonania złączy spawanych, spełanijących kryteria normy ISO 15614-14. Uzyskane złącza próbne charakteryzowały się brakiem niezgodności spawalniczych dotyczących kształtu, geometrii i nieciągłości metalu spoiny na przekroju złącza spawanego. Wytrzymałość na rozciąganie złączy spawanych jest zbliżona do wytrzymałości materiału rodzimego, a własności plastyczne są zadawalające. Próba zginania zarówno od strony lica, jak i grani pozwoliła na osiągnięcie kąta gięcia $180^{\circ}$, a udarność w spoinie, w obszarze linii wtopienia i w SWC spełnia wymagane kryteria minimalnej granicy plastyczności dla złączy spawanych. W obszarze linii wtopienia następuje spadek twardości, ale obejmuje on stosunkowo wąski zakres i nie ma on wpływu na własności eksploatacyjne połączeń spawanych. Przeprowadzone badania mikroskopowe wykonanych połączeń wykazały w spoinie typową strukturę bainityczno - ferrytyczną o charakterze dendrytycznym. Strefa wpływu ciepła charakteryzuje się obszarami o zmiennej wielkości ziarna, wywołanej oddziaływaniem cyklu cieplnego. W SWC oraz w materiale rodzimym zaobserwowano obecność faz mikrododatków umacniających. Są to duże wydzielenia azotków tytanu, na co wskazuje ich kształt oraz duża zawartość tytanu w stali. Wydzieleń tych nie zaobserwowano w spoinie, co może wskazywać na fakt, iż rozpadły się one podczas procesu spawania, co może mieć wpływ na zmiany własności wytrzymałościowych i plastycznych spoiny.

\section{Literatura}

[1] Bagger C., Olsen F.: Review of laser hybrid welding, Journal of Laser Applications, $1 / 2005$

[2] Gawrysiuk W., Siennicki M.: Robotyzacja procesu spawania hybrydowego - przykład aplikacji, Przegląd Spawalnictwa 8/2011

[3] Pilarczyk J., Banasik M., Dworak J., Stano S.: Spawanie hybrydowe z wykorzystaniem wiązki laserowej i łuku elektrycznego, Przegląd Spawalnictwa 10/2007.

[4] Messler R.: What's Next for Hybrid Welding, Welding Journal, 3/2004.

[5] Alam N., Kim Y. P.: Hybrid laser welding- an innovative process for high efficiency welding, Australian Welding Journal 3/2005

[6] Moore P. L., Howse D. S., Wallach E. R.: Development of Nd:YAG laser and laser/MAG hybrid welding for land pipeline applications, Welding and Cutting 3/2004.

[7] Shi S., Hilton P., Mulligan S., Verhaeghe G.: Compensating for changing gap by adaptive control of the hybrid laser-MAG welding process for thick plate, Welding and Cutting 4/2005.

[8] Murakami T., Shin M. H., Nakata K.: Effect of welding direction on weld bead formation in high power fiber laser and MAG arc hybrid welding, Transactions of JWRI 2/2010.

[9] Nishioka K., Ichikawa K.: Progress in termomechanical control of steel plates and their commercialization, Science and Technology of Advanced Materials, vol. 13, No. 2, April 2012, pp. 1-20.
[10] Chen B., Yu H.: Hot ductility behaviour of V-N and V-Nb microalloyed steels, International Journal of Minerals, Metallurgy and Materials, vol. 19, No. 6, June 2012, p. 525.

[11] Lee, H. Shin, K. Park: Evaluation of high strength TMCP steel weld for use in cold regions, Journal of Constructional Steel Research 74 (2012) pp. 134-139.

[12] Górka J.: Influence of welding thermal cycling on the join properties of S700MC steel treated using thermomechanical method, 15 th International Conference on Experimental Mechanics, 22-27 June 2012, Porto, Portugal, pp. 197-198.

[13] Lisiecki A.: Diode laser welding of high yield steel. Proc. of SPIE Vol. 8703, Laser Technology 2012: Applications of Lasers, 87030 S (January 22, 2013), DOI: $10.1117 / 12.2013429$.

[14] Adamczyk J., Opiela M.: Influence of the thermo-mechanical treatment parameters on the inhomogeneity of the austenite structure and mechanical properties of the Cr-Mo steel with $\mathrm{Nb}$, Ti and B microadditions, Journal of Materials Processing Technology, vol. 157-158, 2004, pp. 456-461.

[15] Górka J.: Własności i struktura złączy spawanych stali obrabianej termomechanicznie o wysokiej granicy plastyczności, Wydawnictwo Politechniki Śląskiej, Gliwice 2013.

[16] Grajcar A., Różański M., Stano S.: Effect of heat input on microstructure and hardness distribution of laser welded Si-Al TRIP-type steel, Advances Material Science Engineering. 2014, Article ID 658947, pp. 1-8. 